\title{
Assessing Flood Vulnerability Index for Policy Implications Towards Flood Risk Management Along the Atlantic Coast of Limbe, Cameroon
}

\author{
Usongo Patience Ajonina, Tepoule Nguéke Joseph, Chang Linda Meh \\ Department of Geography, University of Buea, Buea, Cameroon \\ Email address: \\ pusongo@yahoo.com (U. P. Ajonina) \\ To cite this article: \\ Usongo Patience Ajonina, Tepoule Nguéke Joseph, Chang Linda Meh. Assessing Flood Vulnerability Index for Policy Implications Towards \\ Flood Risk Management Along the Atlantic Coast of Limbe, Cameroon. American Journal of Water Science and Engineering. \\ Vol. 7, No. 2, 2021, pp. 24-38. doi: 10.11648/j.ajwse.20210702.11
}

Received: March 9, 2021; Accepted: March 22, 2021; Published: April 7, 2021

\begin{abstract}
Floods along the Atlantic coast of Limbe are the most predominant natural disaster posing serious threats to man and the environment. Without adequate information about the risk levels and why the implementation of locally appropriate adaptation measures are less effective, flood disasters will continue to become more rampant and disastrous. The ability to accurately identify, measure and evaluate the various vulnerabilities of affected people and communities is a right step towards reducing disaster risk. This article focuses on developing a Flood Vulnerability Index (FVI) based on exposure, susceptibility and resilience factors that will guide putting in place specific adaptation plans targeted at reducing the impacts of floods. The study made use of the mixed research design method. Reponses were gathered from 183 respondents using questionnaires and focus group discussions (FGD) from household heads to construct an integrated vulnerability index made up of 22 indicators grouped into susceptibility indicators (15), resilience (5) and exposure (2). A handheld Global Positioning System (GPS) was used in the measurement of distance and elevation. Data collected was subjected to analysis of variance to test if significant differences in vulnerability exist within the neighborhoods and the level of success of adaptation strategies was also investigated. Findings show that Motowo and Church Street have very small vulnerability to floods, Cassava Farm and Clerks Quarters have high vulnerability to floods and Down Beach with an index of 0.84 has a very high vulnerable to floods. From the results coastal communities are significantly different $(p<0.01)$ in terms of vulnerability to flood hazards. A total of $19.39 \%$ of the population highlighted that the adaptation strategies put in place to help combat floods in their neighborhoods are effective while $80.61 \%$ of the respondents decried that the measures were not effective. Coping strategies need to take into consideration the myriad of factors involved in the determination of vulnerability so as to help putting in place a comprehensive multi-risk adaptation strategy. Policies implications of the results warrant a conscious effort by the council to clear chocked gutters, culverts and major drains to ease water flow especially during the rainy seasons and local authorities and ministries must make sure proper land use plans are in place and are enforced without any fear or favor so as to ensure resilience to flood risks.
\end{abstract}

Keywords: Adaptation, Coastal Areas, Exposure, Flood Risk Assessment, Flood Vulnerability Index Introduction

\section{Introduction}

Vulnerability assessments are nowadays considered as key issues towards effective flood disaster risk reduction [1] because in many vulnerable countries, disaster management is mainly concentrated on emergency response, disaster relief, and rehabilitation activities at the expense of site specific socio-economic and environmental conditions. Several studies therefore suggest a paradigm shift from disaster relief

and response to disaster risk and vulnerability reduction $[1,2]$. It is therefore imperative to develop vulnerability indicators which will enable decision-makers to assess the impact of disasters [3] and put in place sustainable measures because of the close relationship between sustainable development and vulnerability assessment. The three main pillars of sustainable development are: social, economic, and environmental $[4,5]$. 
It is evident that social, economic and environmental conditions exist within a society that result to some groups of people living with an amplified state of vulnerability [6]. Assessing vulnerability using the socio-economic and physical dimensions aid in the identification of the most vulnerable regions together with key factors which, once addressed, could increase the resilience of local communities.

Flooding is a major challenge of many coastal cities across the world due to their lower geographic elevations and higher population densities than that of inland communities [7]. Coastal floods are regarded as among the most dangerous and harmful of natural disasters [8] posing serious threats to the environment and development. Satterthwaite [9] found out that many coastal cities lack good infrastructures such as drainage, water storage, sanitation, roads, healthcare and emergency services system. These conditions increase the vulnerability of populations to different forms of hazards [10]. The frequency of flood disasters has amplified throughout the world with the number of disasters and affected people having doubled during 1990 to 2000 [11]. A major contributing factor is climate change which has made human and natural systems more vulnerable to disasters due to its impacts on these systems $[12,13]$. Developing countries are at risk of climate change, and therefore most vulnerable to flood disasters [14], mainly due to lack of resources to adapt (socially, technologically and financially) to such disasters $[15,16]$, the high concentration of economic and industrial development along the coast [17], growing population in the coastal zones [18], low adaptive capacity due to persistent poverty and poor planning [19] and a lack of knowledge on site specific vulnerabilities which have often resulted in not putting in place appropriate measures.

Of all-natural disaster deaths, 97\% occur in developing countries. Asia and Africa are the most affected continents with floods accounting for half of these disasters. Much of Africa is vulnerable to flooding with episodes of floods accounting for $26 \%$ of total disaster occurrences (Institute for Catastrophic Loss Reduction [20]. Floods contribute extensively to loss of life, damage of property, and promote spread of diseases such as malaria, dengue fever and cholera over coastal communities in Africa [21]. From 1900 to 2006, floods in cities of Africa killed nearly 20,000 people and affected approximately 40 million people. Total cost of damage was estimated at about US\$4 billion [22]. Increased flood incidence in African cities has affected poor households and businesses in densely populated areas and economically important coastal communities [23]. Hence, understanding the extent of flood vulnerability and the capacity of local communities to adapt to the impacts should be a call for concern for all stakeholders as a precursor for promoting sustainable management of floods in an era of global climate change. Since global climate change is probably going to accentuate coastal flooding and also exacerbate many other problems already confronting coastal communities in Africa [24], there is a dire need for a regular assessment of vulnerability and coping strategies adopted in order to help community planning and emergency management.
Vulnerability measurement is vital for community planning and emergency management. Vulnerability, often expressed as an index, has been conceptualized in a myriad of ways. A number of studies have demonstrated various approaches for coastal vulnerability assessment [25-27]. The vulnerability of a community to a flood hazard is often measured using socioeconomic indicators or calculating physical flood extents. However, their combined impact is usually ignored.

Cameroon like many other developing countries still suffer devastating effects of floods. Limbe a coastal town has recorded devastating floods over the years and factors accounting for the perennial floods in Limbe remain both natural and human [28]. Flooding has greatly impacted the town by enormously damaging property and infrastructure, resulting to substantial loss of lives and livelihoods of community members. The floods of June 2001 and July 2014 affected about 3000 inhabitants, notably, within the neighborhoods of Mabeta, New layout, Mile 2, Towe, Clerks Quarters, Livanda, Congo Moyo, Motowo, Mbonjo and Mbende [28]. There was the loss of 23 human lives, about 50 persons were injured, 78 houses were completely destroyed, community infrastructure (roads, water and electricity supply lines, communication systems, schools, hospitals, churches, etc.) were disrupted and the environment was polluted and degraded. Indirect losses include: unemployment, disruption of economic activities and livelihoods. All loses were estimated at CFA 1.5 billion Frs. (\$3 million U. S) [28]. Although disaster management plans at local, regional and national levels are available and are regularly updated annually, there are still not able to manage floods and reduce damages and community vulnerabilities. The few studies so far carried out in the area are those characterizing the outcomes of flood hazards and how vulnerable populations perceive and adapt to flood risks [29, 30]. To fill the gap additional research is imperative to examine the perceived causes of floods and provide a practical identification and assessment of socio-economic and physical vulnerabilities in the area by assigning measurable numeric indicators to serve as a good reference and a scientific foundation to local authorities in flood disaster mitigation as well as well as aid in generating a sound flood mitigation program for Limbe. This study was aimed at calculating the FVI and to proposes policy implications for flood risk management along the Atlantic coast. It sets out to answer the following research questions: (1) What are the perceived causes of flood disaster? (2) What are the adaptation measures put in place and how effective are these measures? (3) How have the socio-economic dimension of susceptibility, socio-economic indicators of resilience and the physical indicators of exposure influence the FVI in the area? (4) What policies need to be proposed in order to ensure the sustainable management of floods?

\section{Materials and Methods}

\subsection{Study Area}

Limbe is located between Latitude $4^{\circ} .02$ north of the 
equator and longitude $9^{\circ} .21$ east of the Greenwich Meridian and it is situated at an elevation of 69 meters above sea level. It is a natural coastal and exotic city nestled between the Cameroon Mountain (Mount Fako) and the Atlantic Ocean. It is the link between the ocean and the continental segment of the Cameroon Volcanic Line (CVL) and is found where the Cameroon Mountain extends into the Gulf of Guinea. Limbe has a total surface area of $549 \mathrm{~km}^{2}$ and its coastline is dominated by volcanic rocks that stretch from Debundscha (the second wettest place in the world) to Man O'War Bay. Figure 1 shows the location and sample sites within Limbe 1 municipality in Fako Division, South West Region. Limbe I council area has an equatorial climate with annual average temperature of $27^{\circ} \mathrm{C}$ and an annual average rainfall of above $500 \mathrm{~mm}$. The annual temperature range is $21.45^{\circ} \mathrm{C}$ to $32.75^{\circ} \mathrm{C}$. The rainfall varies from $114.0 \mathrm{~mm}$ to $1053.0 \mathrm{~mm}$ per month. Peak rainfall is experienced during the rainy season which lasts from mid-June to October. The dry season records the lowest amount of rainfall which lasts from November to April ending.
The city is a low-lying coastal plain with the highest points reaching $362 \mathrm{~m}$ above sea level [31]. Within the town of Limbe, small streams flow into larger drainage beds that converge into two main rivers (Limbe and Jenguele) that empty into the Atlantic Ocean. These rivers frequently overflow their banks in the rainy season causing floods in the low-lying areas that are just $1-2 \mathrm{~m}$ above sea level. The water table is highly stable and high in areas like Clerks Quarters thereby impeding infiltration following rainfall making the area vulnerable to floods. Figure 2 shows the drainage map of Limbe 1 .

The population of Limbe is estimated at 120000 inhabitants according to the 2007 census. A drive through the city indicates an acute spatial disorganized view of settlements with a mixture of planned and unplanned settlements. The city generates so much garbage daily, of which the council is unable to collect due to their existing capacity and facilities. It is very common to find garbage poorly disposed in drains, gutters, along river banks and illegal dumpsites. Following heavy rainfall most of the waste is carried by runoff blocking gutters and drains and increasing the risk of flooding

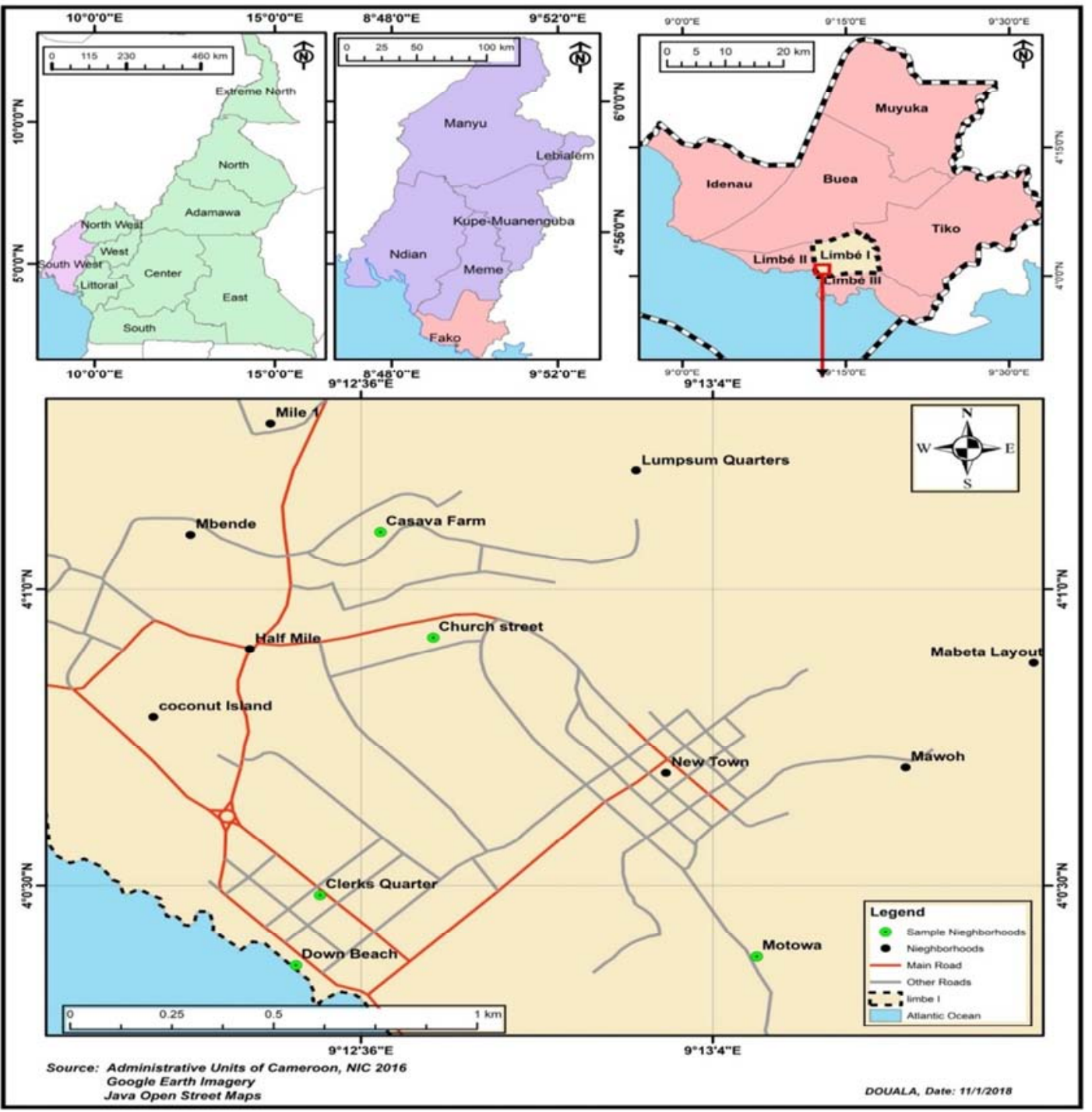

Figure 1. The location map of Limbe 1 municipality. 

Risk Management Along the Atlantic Coast of Limbe, Cameroon

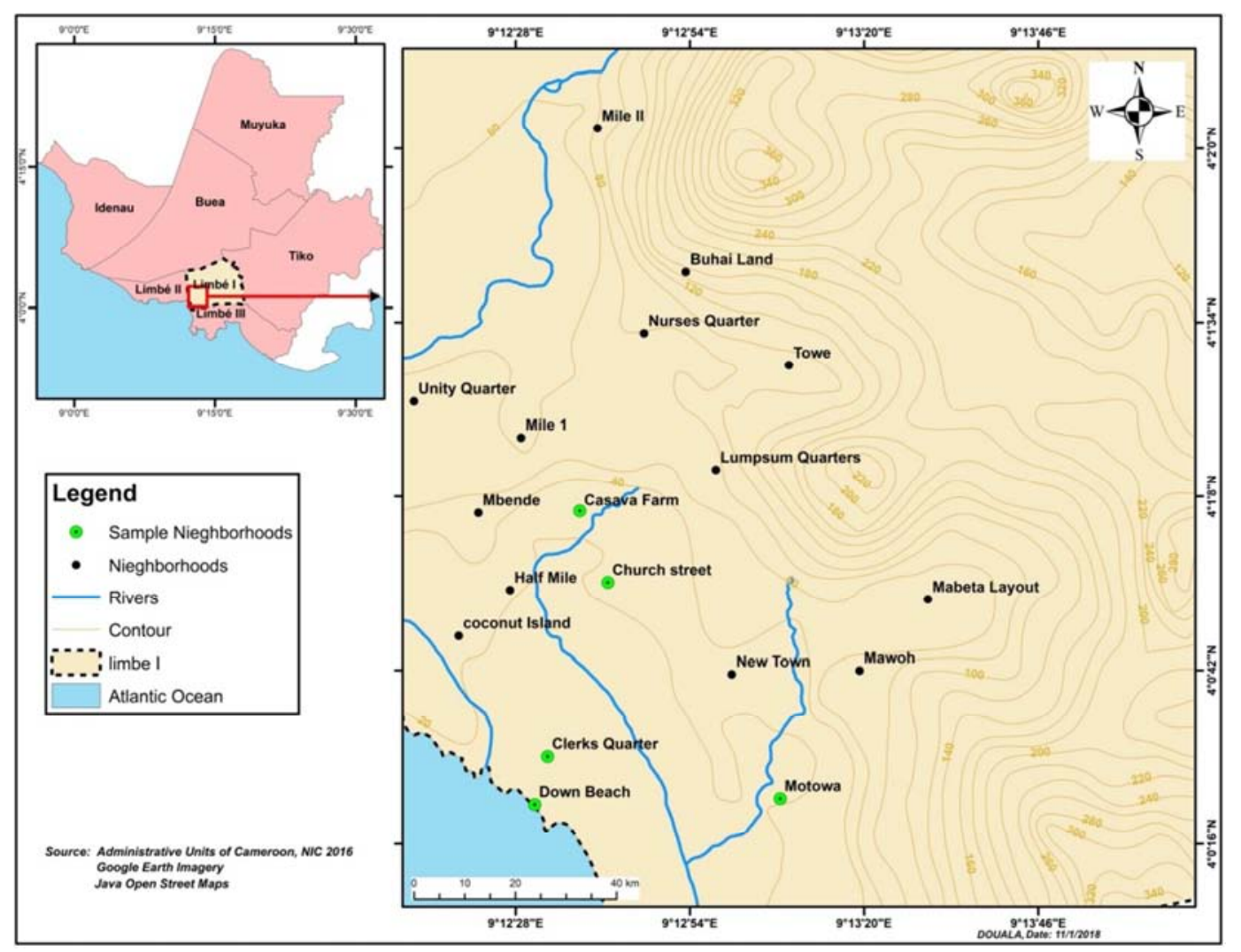

Figure 2. Drainage map of Limbe 1.

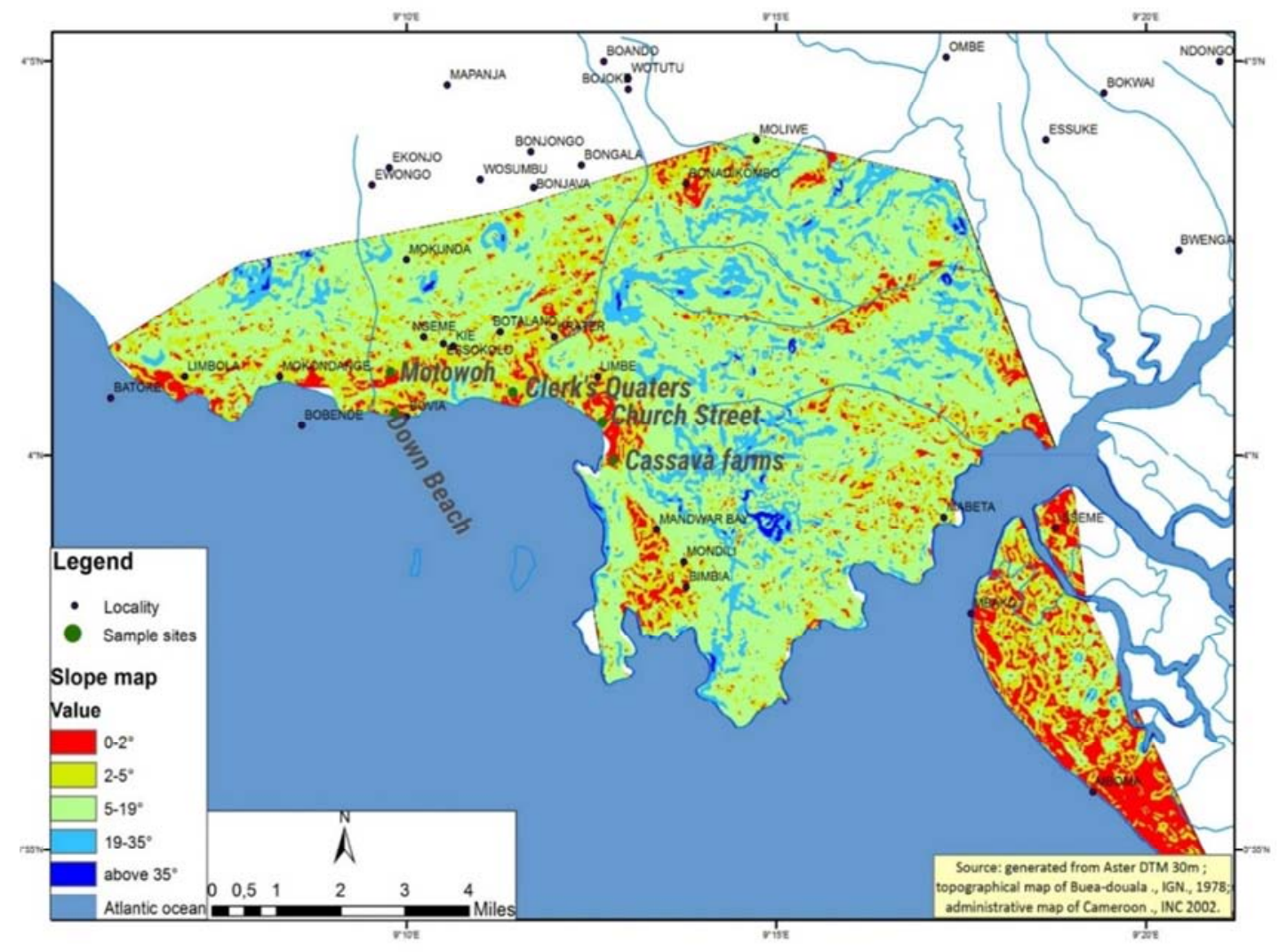

Source: Generated from Aster DEM 2018.

Figure 3. Slope map of Limbe showing the sample sites. 


\subsection{Sampling Procedure and Sample Sites Selection}

A multi-stage random sampling design with a two-stage sampling was used for the study. The first stage was the selection of the sampled sites. It involved communities located along the Atlantic coast. A stratified random sampling design was used in selecting the sampling sites. To achieve this, the map of the area was super imposed on a digital elevation model (DEM) image of the area from where a slope map was generated with values ranging $0-2^{\circ}$ to above $35^{\circ}$ (Figure 3). Five sample sites with slopes values of $0-2^{\circ}$ indicating a high vulnerability to flood hazard were randomly selected for the study. The communities selected were: Cassava Farms, Clerks Quarters, Church Street, Motowoh and Down Beach communities.

The second stage involved the selection of the sample population for vulnerability assessment and adaptation strategies put in place. A systematic random sampling design was used in selecting the households for interviews and questionnaires administration. It involved selecting a sample unit at random, then selecting every nth unit systematically. The nth unit varied depending on the number of households. In large communities, a step of 5 houses was chosen while in small communities there was a step of 3 houses. Within the 5 communities, household heads were chosen.

\subsection{Flood Vulnerability Indicators Selection}

Vulnerability is 'the characteristic of a community's system that make it susceptible to the damaging impacts of a hazard' according to the United Nations International Strategy for Disaster Reduction [32]. Vulnerability is determined by the physical, social, economic, and environmental factors, which can increase susceptibility to the impact of hazards' [33, 34].
The United Nations Development Programme (UNDP) defines vulnerability as 'a human condition or process resulting from physical, social, economic and environmental factors, which determine the likelihood and scale of damage from the impact of a given hazard' [35]. Assessing vulnerability involved analyzing the elements of exposure, susceptibility and resilience of any system to a hazard [7].

Exposure and susceptibility are considered as the stressors of the system which increase vulnerability while resilience is considered as the potential of the system to reduce the impact of the hazard. Exposure is defined as 'the degree, duration and/or extent to which a system is in contact with, or subject to, perturbation' [36, 37]. Most environments or communities are exposed to hazards by virtue of their location. Susceptibility reflects the capacity of individuals, groups, or physical or socio-economic systems to withstand the impact of the hazard. Susceptibility s defined as the elements exposed within the system, which influence the probabilities of being harmed during floods. The susceptibility indicators embrace general information on social relations, climate and population with special needs (children, elderly or disabled) among others. Resilience is the success of adaptation measures despite challenging circumstances. Resilient indicators are those that can help give us a clue on the success of the coping measures put in place, the way the population perceive floods and presence of structures and measures that can aid the community to adjust and cope with the impacts of flood hazards.

The selection of appropriate indicators for the study was done using a deductive approach based on existing principles and the concepts of vulnerability. A total of 22 variables were selected, representing the most relevant factors shown to influence vulnerability to flood hazards and were grouped into susceptibility indicators (15), exposure (2) and resilience (5) as shown on Figure 4.

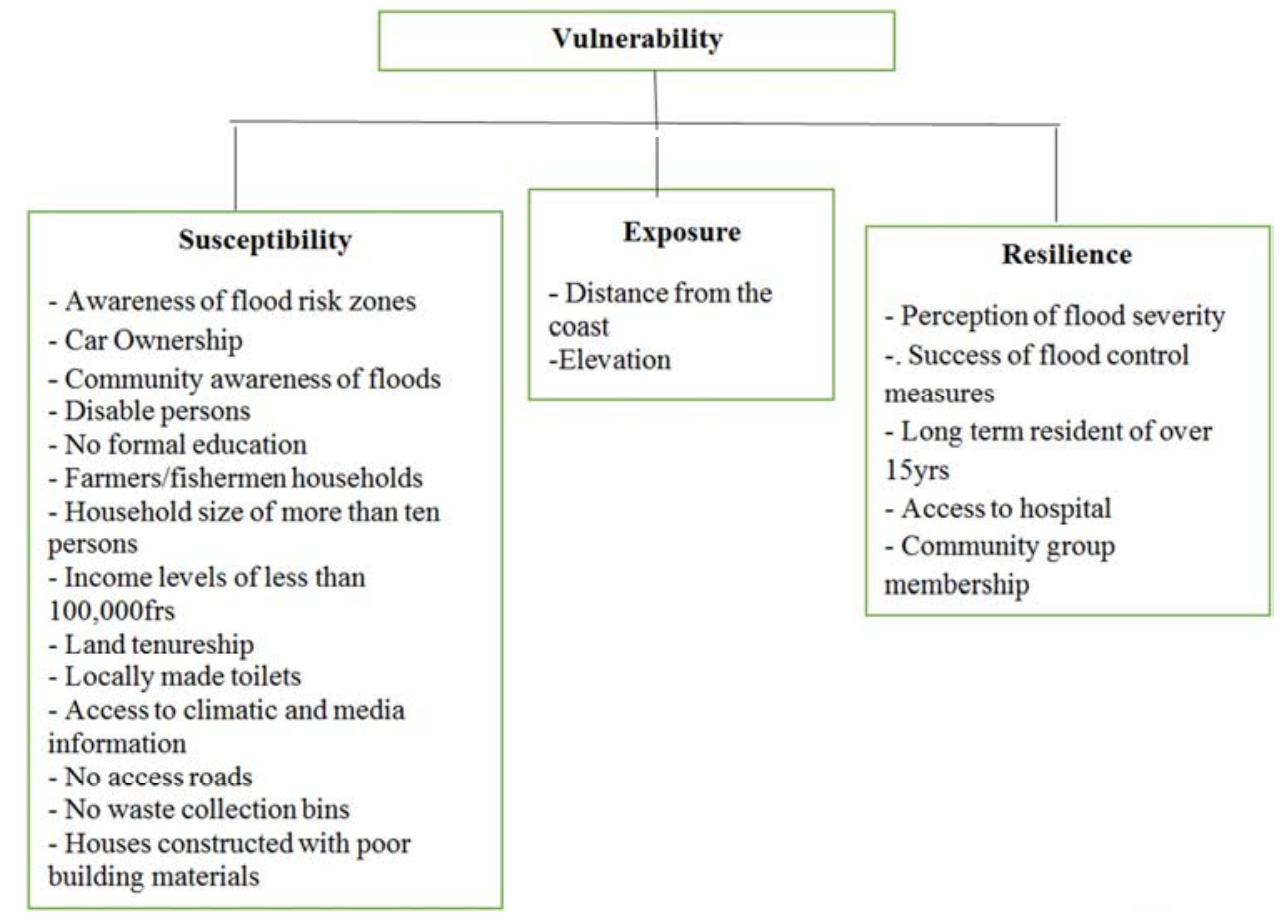

Figure 4. Vulnerability assessment indicators for the study. 


\subsection{Data Collection Methods}

The study made use of primary and secondary data sources. Primary data was obtained using a hand held Global Positioning System (GPS) to take the elevation and distance from the coast to selected neighborhoods. Socioeconomic indicators of susceptibility and resilience were collected through questionnaire-based interviews at household levels and personal observation. Secondary data was obtained from various sources such as journal articles and other documented sources. Maps were also generated from the United States Geologic Survey (USGS), Aster DEM data base via ArcGIS and QGIS software. Some secondary information was also gotten from the council pertaining to the details of the study area.

\subsection{Vulnerability Assessment}

Societies are vulnerable to floods due to three main factors: exposure, susceptibility and resilience [38]. This study made use of the system approach to identify the interactions of different actors or components within the coastal system [7]. In this study, the vulnerable people in a community were expressed in two closely linked ways: (1) socio-economic vulnerability (susceptibility) and (2) physical vulnerability (flood exposure) The vulnerability assessment method used was the vulnerability index system. Defined indicators related to susceptibility and exposure were measured.

The procedure for calculating the Flood Vulnerability Index (FVI) starts by converting each identified indicator into a normalized value (on a scale from 0 to 1 ), dimensionless number using predefined minimum and maximum values from the spatial elements under consideration. Standardization of indicators' values is expected to create a comparative proportion among the indicators.

The formula used for normalization was:

$$
\mathrm{V}_{\mathrm{I}}=\left(\mathrm{X}_{\mathrm{ij}}-\operatorname{Min} \mathrm{X}_{\mathrm{i}}\right) /\left(\operatorname{Max}_{\mathrm{Xi}}-\operatorname{Min}_{\mathrm{i}}\right)
$$

where

$\mathrm{V}_{\mathrm{ij}}=$ the standardized vulnerability index for a vulnerability parameter $\mathrm{i}$ for a vulnerable place $\mathrm{j}$

$\mathrm{X}_{\mathrm{ij}}=$ the observed value of a particular place $\mathrm{j}$ for a particular vulnerability parameter $\mathrm{i}$

Min $\mathrm{X}_{\mathrm{i}}$ and Max $\mathrm{X}_{\mathrm{i}}=$ the minimum and maximum values of the observed range of values of a vulnerability parameter

Normalized indicators were subsequently used for vulnerability indices calculations. The FVI of each coastal component (socio-economic and physical) was computed based on the general flood vulnerability index (FVI) formula (Eq. 2).

\section{$\mathrm{FVI}=\mathrm{E} * \mathrm{~S} / \mathrm{R}$}

The general formula for FVI was computed by categorizing the indicators of the factors of exposure (E), susceptibility (S) and resilience $(\mathrm{R})$ according to [39].

With regards to coastal vulnerability indicators equation (2) was transformed to represent the different vulnerability dimensions to be used in the study. An aggregate value of socioeconomic vulnerability of various neighborhoods was calculated as the average of standardized indicators values using the following equation according to [40]

$$
\text { Socioeconomic Vulnerability (susceptibility) }=\frac{\text { SSEI } 1+\text { SSEI } 2+------- \text { SSEIX }}{\mathrm{X}}
$$

Where SSEI1=Standardized socio-economic indicator 1

SSEIX $=$ Standardized socio-economic indicator $\mathrm{X}$

$\mathrm{X}=$ maximum number of indicators
Physical vulnerability was calculated using the normalized ranked values of altitude and distance from the coast using the following equation.

$$
\text { Physical vulnerability }(\text { exposure })=\frac{\text { SPI1 + SPI2+----------SPIY }}{\mathrm{Y}}
$$

Where SPI1 $=$ Standardized physical indicator 1

SPI2=Standardized physical indicator 2

SPIY $=$ Standardized physical indicator $Y$

$\mathrm{Y}=$ maximum number of indicators

Resilience was also calculated using the normalized values of resilience indicators with the following equation.

$$
\text { Resilience }=\frac{\text { SRI } 1+\text { SRI2 }+--------- \text { SRIZ }}{\mathrm{Z}}
$$

Where SRI1 $=$ Standardized resilience indicator 1 SRI2 $=$ Standardized resilience indicator 2 $\mathrm{SRIZ}=$ Standardized physical indicator $\mathrm{Z}$

$\mathrm{Z}=$ maximum number of indicators

The total FVI of each sample site is the average of four FVI (Eq 3-5) and the result was interpreted following [7] flood vulnerability interpretation as seen on Table 1 below. The index is expressed on a scale from 0-1 signifying low or high flood vulnerability and shows which areas need detailed investigation for selecting more effective measures and appropriate strategies to be undertaken.

Table 1. Flood vulnerability interpretation scale (after [7]).

\begin{tabular}{ll}
\hline Index value & Description \\
\hline$<0.01$ & Very small vulnerability to floods \\
$0.01-0.25$ & Small vulnerability to floods \\
$0.25-0.50$ & Vulnerable to floods \\
$0.50-0.75$ & High vulnerability to floods \\
$0.75-1$ & Very high vulnerability to floods \\
\hline
\end{tabular}

\subsection{Statistical Analysis}

The analysis of variance was used to test the vulnerability within the neighborhoods. Results of the FVI for the different neighborhoods were subjected to statistical analysis. One-way ANOVA using the SPSS version 18.0 package was performed 
to investigate whether significant variations in vulnerability do occur over space in the area.

\section{Results and Discussions}

\subsection{Perceived Causes of Flood Disaster}

People tend to adjust to natural hazards based on what they think are the causes. The study revealed that the causes of floods in Limbe are multifaceted as shown on Figure 5. Floods in Limbe have been linked to several causes

A majority of the respondents (78\%) identified high rainfall as the main cause of flooding in Limbe. Another finding was that temperature has increased over time. The changes in the climate based on temperature, supports the position of [41] that global temperature will increase by $6.4 \%$ by the end of this century with sea level rising at a rate of $59 \mathrm{~cm}$. Several studies have also linked flood events to climatic factors [42].
This also tallies with the findings of [43] who stated that floods are natural phenomenon aggravated by extreme climate change and hydro-meteorological events.

Apart from the physical problem of climate, respondents also identified human induced causes as catalysts to the extent of damage on properties and loss of lives. A total of $30.6 \%$ respondents mentioned wastes thrown in drains as the major human induced cause of floods in Limbe. Indiscriminate disposal of refuse into streams and storm drains, construction of undersized drains and culverts often blocked the free flow of runoff resulting to floods. This is in line with the work of $[44,45]$ who said that, although about 60 to $75 \%$ of solid waste generated in the city is collected, the solid waste that remains uncollected often finds its way into open drains, thus obstructing the free flow of water causing overflows that result in floods.

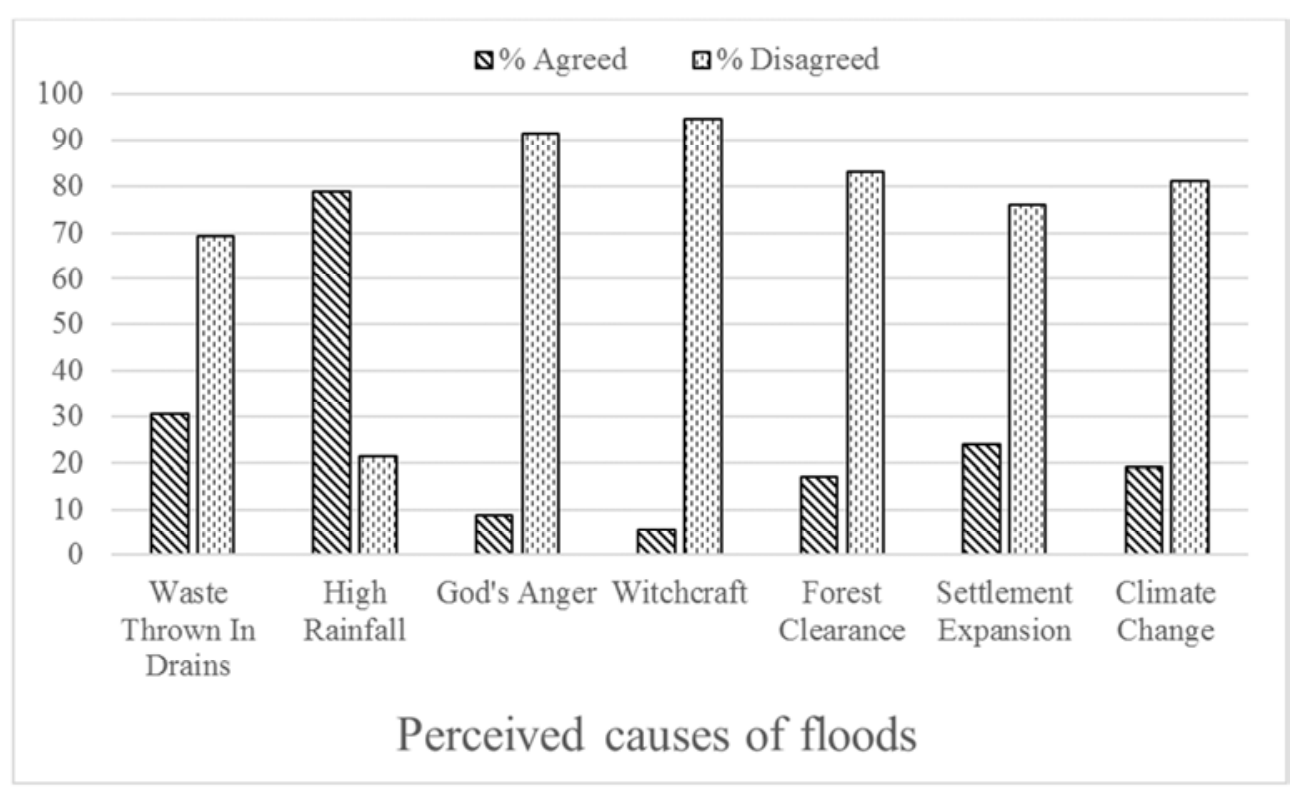

Figure 5. Household perception on the causes of flood in Limbe.

Other human induced causes were settlement expansion $(24.0 \%)$, Gods anger $(8.7 \%)$, witchcraft $(5.5 \%)$, clearance of forest lands (16.9\%) and building within flood plains. Population increase and pressure in the area has pushed many to construct houses on marginal lands. According to [9], hundreds of millions of urban dwellers live-in poor-quality homes on illegally acquired and marginal lands. This reduces the desires of individuals to invest in more resilient building structures and areas. As a result, many wooden structures are found in these areas. The increasing practice of building on watercourses and wetlands, indiscriminate dumping and silting of drains has exacerbated the perennial urban floods in Limbe. This result confirms the findings of [46, 47] who highlighted that increase incidence of floods is because of the low-lying nature of the land, high rainfall intensity and duration, deposition of sediments in storm drains

\subsection{Socio-economic Dimension of Susceptibility}

Table 2 below presents the results of the 15 socio-economic susceptibility indicators measured.

Field results show that $31.4 \%$ of households in Down Beach are not aware of flood risk zones as compared to only $14.6 \%$ in Cassava Farm. Poor knowledge of flood risk zones can result in the construction of houses in zones that are prone to floods. With the exception of Clerks Quarters where only $21.6 \%$ of the population have no cars, all the other neighborhoods have more than $60 \%$ of their population with no cars thereby hindering fast evacuation whenever there are floods. The high proportion with no car ownership is because of the high rate of poverty within the neighborhoods. The findings of [48] supports this trend that vulnerability results from poverty. 
Table 2. Socio-economic indicators of susceptibility showing the percentage of households affected.

\begin{tabular}{|c|c|c|c|c|c|}
\hline \multirow{3}{*}{ Susceptibility Indicators } & \multicolumn{5}{|c|}{ Sample Sites showing \% households } \\
\hline & \multicolumn{5}{|c|}{ Neighborhood } \\
\hline & Cassava Farm & Church Street & Clerks Quarters & Down Beach & Motowo \\
\hline Aware of flood risk zones & 14.6 & 19.4 & 19.4 & 31.4 & 14.7 \\
\hline Car ownership & 75.6 & 80.6 & 21.6 & 62.9 & 70.6 \\
\hline Community Awareness & 7.3 & 2.8 & 8.1 & 11.4 & 2.9 \\
\hline Disable people & 7.3 & 22.2 & 18.9 & 14.2 & 26.5 \\
\hline Education: no schooling & 7.3 & 0 & 8.1 & 8.5 & 11.8 \\
\hline Household size (more than 10 ) & 12.5 & 3.4 & 3.8 & 7.1 & 12.5 \\
\hline Income below 100,000 frs & 58.5 & 22.2 & 32 & 22.9 & 32.4 \\
\hline Land ownership & 7.3 & 22.2 & 18.9 & 22.9 & 47.1 \\
\hline Locally made toilets & 14.6 & 8.3 & 10.8 & 25.7 & 32.4 \\
\hline No access to climatic information & 78.1 & 77.8 & 81.1 & 74.3 & 73.5 \\
\hline No access to media information & 7.3 & 25 & 10.8 & 8.6 & 17.7 \\
\hline No access to road & 12.2 & 13.9 & 21.6 & 11.4 & 26.5 \\
\hline
\end{tabular}

With regards to community awareness of floods, results revealed that with the exception of Down Beach with $11.2 \%$ of households not aware of floods, the other neighborhoods have less than $8 \%$ of their population not having a knowledge of floods. Knowledge of flood awareness is important because awareness is a necessary precursor to preparedness.

Results from the field further show that the percentage of households with disable persons in Motowo was 24.5\% and $22.2 \%$ in Church Street making then the most susceptible neighborhoods than the other neighborhoods of the study. This is because in times of floods those who are not disabled can easily escape from the hazard than those who are disabled there by increasing the mortality rates in these neighborhoods in times of flooding. This corrobates with the work of [26] who states that the disabled are particularly vulnerable.

Percentage household heads that have not been to school were $7.3 \%, 8.1 \%, 8.5 \%$ and $11.5 \%$ respectively for Cassava Farm, Clerks Quarter, Down Beach and Motowo. The inability to read and understand disaster communication makes many communities to be more vulnerable to floods. Field results revealed that Cassava Farm and Motowo have $14.6 \%$ and $14.7 \%$ respectively farmers'/fishermen household compared to other neighborhoods with just $8.3 \%$. Where household heads are predominantly made up of farmers/fishermen the neighborhood is bound to be more susceptible to floods compared to those that are predominantly dominated by civil servants. This is because the level of exposure, reasoning faculty, income levels and the manner in which they perceive and cope with floods are different. Cassava Farm and Motowo have $12.5 \%$ of households having more than ten persons while Clerk Quarters and Church Street have less than $4 \%$ of household sizes of more than ten persons indicating a lower susceptibility to floods. From the results $58.5 \%$ of household heads within Cassava Farm have income levels below 100,000frs while the other neighborhoods have less than $33 \%$ household heads within this income level. thereby making them to be more susceptible to flood as they will turn to occupy the most hazardous geographical areas and most poorly maintained buildings, which result in the greatest physical impacts such as casualties and property loss during a disaster This relates to the findings of [49], who stated that; poverty is a major factor that increases vulnerability and impacts of floods.

Percentage tenant households recorded by the study was $47.1 \%$ in Motowo, 22.9\% in Down Beach, 22.2 in Church Street, 18.9\% in Clerks Quarters and 7.3\% in Cassava Farm. Land tenurership can strongly influence the level of control a resident has over the adoption of protective measures leading to differences in flood susceptibility among owners and renters.

Results revealed that 32.4\% households in Motowo, 25.7\% in Down Beach, $14.6 \%$ in Cassava Farm, $10.8 \%$ in Clerks Quarters and $8.3 \%$ in Church Street are using locally made toilets (Table 2). Neighborhoods with such toilets are highly affected during floods exposing the population to health risks through the contamination of water sources resulting to a high prevalence of waterborne diseases. The findings of [50] support the trend that most urban poor dwellers are increasingly exposed to hazards due to the poor conditions they are subject to.

Access to climatic and media information is important in creating awareness on the probability of a flood occurring thereby enabling preparedness. More than $70 \%$ of households in all the neighborhoods attest to the fact that they do not have access to climatic data nor information on early warning signals of flood occurrences.

With the exception of Church Street neighborhood where $25 \%$ of households attest to not having access to media information, less than $18 \%$ households do not have access to media information in the other neighborhoods. The percentage of households with no access roads was $12.2 \%, 13.9 \%, 21.6 \%$, $11.4 \%$ and $26.5 \%$ respectively for Cassava Farm, Church Street, Clerks Quarters, Down Beach and Motowo. Areas with no access roads will hinder movements of persons and property resulting to heavy casualties and damages.

The percentage of household with no access to waste collection bins is $31.7 \%, 20.6 \% 19.4 \%, 18.9 \%$ and $40 \%$ respectively for Cassava Farm, Motowo, Church Street, Clerks Quatres and Down Beach. This indicates that Down 
Beach and Cassava Farm neighborhoods are more susceptible to floods that can result due to poor waste disposal than the other neighborhoods.

A total of $29.4 \%$ households in Motowo, $27 \%$ in Clerks Quarter, 20\% in Down Beach, 19.4\% in Church Street and $17.4 \%$ in Cassava Farm are living in poorly constructed houses that cannot resist the force of flood waters.

\subsection{Socio-economic Indicators of Resilience}

The analysis of the five resilience indicators are presented on Table 3.

Table 3. Socio-economic indicators of resilience showing percentage of households.

\begin{tabular}{|c|c|c|c|c|c|}
\hline \multirow{2}{*}{ Resilience indicators } & \multicolumn{5}{|c|}{ Sample sites showing \% of household } \\
\hline & Cassava Farm & Church Street & Clerks Quarters & Down Beach & Motowo \\
\hline Perception of flood severity & 37.1 & 55.9 & 46.3 & 56.8 & 47.2 \\
\hline Success of flood control measures & 21.6 & 24 & 14.6 & 24 & 17 \\
\hline Long term resident 15 years & 11.4 & 23.5 & 22 & 21.6 & 33.3 \\
\hline Access to hospital & 90.2 & 63.9 & 78.4 & 74.3 & 52.9 \\
\hline Community group membership & 24.4 & 44.4 & 29.7 & 25.7 & 35.3 \\
\hline
\end{tabular}

Results revealed that $55.9 \%$ of the population in Church Street agreed to the fact that floods in the past were more severe than current floods. The persons that agreed to this statement were $56.8 \%$ in Down Beach, $46.3 \%$ in Clerks Quarters, $47.2 \%$ in Motowo and $37.1 \%$ in Cassava Farm (Table 3). Floods are believed to reduce following the putting in place better coping measures to reduce their impacts. Within the Down Beach and Church Street neighborhoods, 24\% of the households attested to the success of flood control measures, $21.6 \%$ in Cassava Farm, 17\% in Motowo and 14.6\% in Clerks Quarters. The percentage of the total sampled population with long term resident of over 15 years as revealed by the study is as follows: $33.3 \%$ in Motowo, $23.5 \%$ in Church Street, 22\% in Clerks Quarters, 21.6\% in Down Beach and $11.4 \%$ in Cassava Farm. Longer duration of stay is associated with greater awareness, understanding and personal action. It is believed that longevity in an area not only gives more experience but the buildup of adaptive measures over the years which go a long way to guarantee resilience. The percentage of the population having access to hospital in the study area is $90.2 \%$ in Cassava Farm, $76.4 \%$ in Clerks Quarters, 74.3\% in Down Beach, 63.9\% in Church Street and $52.9 \%$ in Motowo. Casualties from injuries and illnesses following a flood event will drastically be reduced where there is access to medical facilities. Results indicated that $44.4 \%$ and $35.5 \%$ of the population of Church Street and Motowo respectively are members of a community group while the representation in the other neighborhoods is less than $30 \%$. Community group membership is an important aspect of community mobilization targeted at carrying out activities such as cleaning of drains and gutters to facilitate the free flow of flood waters, building of sand bags to prevent the encroachment of flood water among others.

\subsection{Physical Indicators of Exposure}

Two indicators selected to measure exposure were elevation and distance from the coast as seen on Table 4 below.

Table 4. Physical indicators of exposure.

\begin{tabular}{|c|c|c|c|c|c|c|}
\hline \multirow{2}{*}{ Indicator } & \multicolumn{6}{|l|}{ Neighborhoods } \\
\hline & Cassava Farm & Church Street & Clerks Quarters & Down Beach & Motowo & Mean \\
\hline Distance from the coast $(\mathrm{m})$ & 204 & 586 & 436 & 173 & 614 & 403.26 \\
\hline Elevation $(\mathrm{m})$ & 18 & 14 & 5.3 & 7 & 17 & 12,3 \\
\hline
\end{tabular}

Results obtained from the field show that the neighborhoods are variably exposed to flood hazards in Limbe Down Beach which is situated at $173 \mathrm{~m}$ from the Atlantic coast is more exposed while Motowo with a distance of $614 \mathrm{~m}$ from the coast is the least exposed. Field results obtained revealed that the height above sea level ranges from $5.3 \mathrm{~m}$ in Clerks Quarters to $18 \mathrm{~m}$ in Cassava Farm showing that Clerks Quarters is the most exposed neighborhood and Cassava Farm the least exposed.

\subsection{Vulnerability Assessment}

The susceptibility, exposure and resilience indices were calculated for all the neighborhoods and the results can be seen on Table 5.

The susceptibility index ranges from 0.29 in Cassava Farm to 0.65 in Motowo (Table 5). Motowo is highly susceptible to floods compared to other neighborhoods. This is not surprising since in 8 out of the 15 indicators under susceptibility (Table 2), Motowo recorded the highest percentage in number of disable people $(26.5 \%)$, persons with no formal education (11.8\%), farmers / fishermen households (14.7\%), household size (more than 10 persons) $(12.5 \%)$, locally made toilets (32.4.7\%), no access to media information $(17.7 \%)$, no access to road $(26.5 \%)$ and poor building material (29.4\%) compared to other neighborhoods.

The index of exposure ranged from 0.88 in Down Beach to 0.13 in Motowo. Down Beach is the most exposed neighborhood to floods. Locational factor of distance to the sea is highly responsible for this. The distance to sea (coastline) is $173 \mathrm{~m}$ which is the closest compared to other neighborhoods. Clerks Quarters is exposed by virtue of its lowest height above sea level which averagely is $5.3 \mathrm{~m}$.

The resilience index ranged from 0.3 in Cassava Farm to 0,52 in Church Street. Church Street is the most resilient 
neighborhood and some of the factors that have contributed to this include; secured buildings with only $(17.4 \%)$ of houses constructed with poor building materials, high access to hospital facilities $(90 . .2 \%)$ and low perception of flood severity $(37.1 \%)$ a higher elevation of $18 \mathrm{~m}$ above sea level compared to other neighborhoods. Vulnerability to flood according to [51] varies due to socio-economic status, available knowledge on flooding and attitudes of people towards environmental management

Table 5. Susceptibility, exposure and resilience indices.

\begin{tabular}{lllllll}
\hline \multirow{2}{*}{ Factor } & Sample sites & & & \\
\cline { 2 - 5 } & Cassava Farm & Church Street & Clerks Quarters & Down Beach & Motowo \\
\hline Susceptibility & 0.44 & 0.29 & 0.37 & 0.45 & 0.65 \\
Exposure & 0.38 & 0.38 & 0.75 & 0.88 & 0.44 \\
Resilience & 0.3 & 0.52 & 0.39 & 0.47 & 0.5 \\
\hline
\end{tabular}

The total vulnerability index was calculated and the results are presented on Figure 6. Based on the flood vulnerability interpretation of [7] Motowo and Church Street have very small vulnerability to floods, Cassava Farm and Clerks Quarters have high vulnerabilities to floods and Down Beach with an index of 0.84 has a very high vulnerable to floods. The high vulnerability of Clerks Quarters and the very high vulnerability of Down Beach are due to locational or physical factors such as average distance to the sea and elevation. They are very close to the sea and have lower elevations.

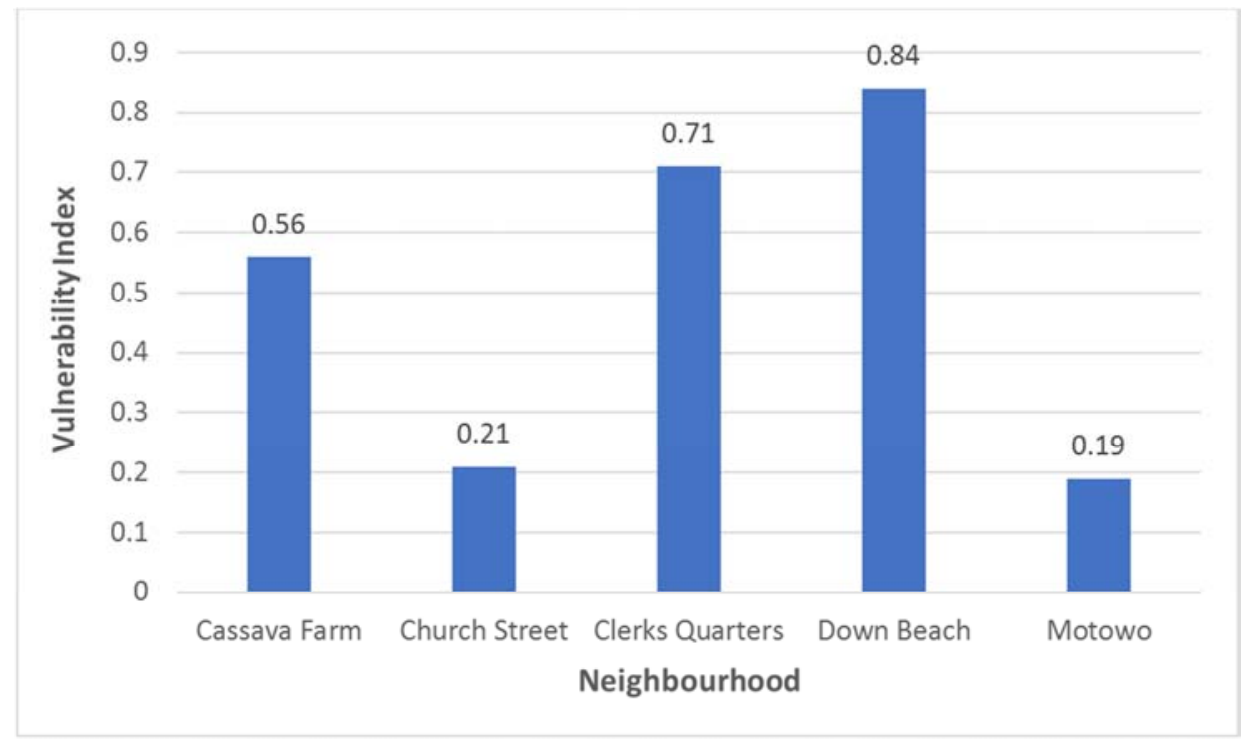

Figure 6. Flood vulnerability index.

The results obtained were subjected to ANOVA to see whether there exists a significant difference in vulnerability to floods within the neighborhoods. The results show that coastal communities are significantly different $(\mathrm{p}<0.01, \mathrm{~F}=26.700$, $\mathrm{df}=2$ ) in terms vulnerability to flood hazards in Limbe. In other words, there are neighborhoods that are more vulnerable than others. This is in line with the work of [51] who also reported variations in flood vulnerability in Vietnam.

This study has presented a comprehensive baseline understanding of location-specific vulnerability assessment to flood risk along the coast of Limbe, where despite frequent occurrences of floods, data on which specific population groups are at a higher risk are lacking. By providing the relative vulnerability of different communities under relatively similar climate conditions, the study has brought to light a critical understanding of the key factors that drive location-specific vulnerability. Therefore, this can form the basis for developing context-specific adaptation and mitigation options to flood vulnerability.

\subsection{Adaptation Strategies to Flood Disaster}

Urban areas are not prone to disaster by nature alone; but also due to other factors such as the socio-economic conditions and processes, rapid urbanization and migration which also increase the risk of urban dwellers to flood disasters. Migrants, settle in areas that originally are liable to floods with pre-existing weak structural conditions with severe consequences. The adaptation measures identified in the study area together with the percentage of those adopting were; relocation (63.95), the building of sandbags (66.7\%), construction of embankments $(69.9 \%)$, building of flood defense walls $(63.9 \%)$, joining community group works (53\%), construction of retainer walls $(66.1 \%)$ and having a house flood plan $(76.5 \%)$ as shown on Table 6 . These strategies were identified not to be effective in the study area. It was noticed that only a small proportion (19.39\%) of the population highlighted that the adaptation strategies put in place to help combat floods in their neighborhoods are effective while $80.61 \%$ of the respondents decried that the 
measures were not effective. However, mitigation measures so far put in place are not very effective because they have failed to address generally the diverse causes of floods and also to take into consideration location-specific peculiarities of flood vulnerability resulting to severe impacts of floods in the area.

Table 6. Adaptation Strategies to Flood Incidences in Limbe.

\begin{tabular}{|c|c|c|c|c|c|c|c|c|c|}
\hline \multicolumn{10}{|c|}{ Current Adaptation Strategies to Flood Incidences in Limbe } \\
\hline Parameters & Relocation & $\begin{array}{l}\text { Building of } \\
\text { sand bags } \\
\text { around } \\
\text { water entry } \\
\text { points }\end{array}$ & $\begin{array}{l}\text { Construct } \\
\text { embankment } \\
\text { around your } \\
\text { nearby } \\
\text { stream }\end{array}$ & $\begin{array}{l}\text { Construction } \\
\text { of retainer wall }\end{array}$ & $\begin{array}{l}\text { Construction } \\
\text { of flood } \\
\text { defense wall }\end{array}$ & $\begin{array}{l}\text { Community } \\
\text { group work }\end{array}$ & $\begin{array}{l}\text { Tree } \\
\text { Planting }\end{array}$ & $\begin{array}{l}\text { Raise your } \\
\text { well/borehol } \\
\text { e above flood } \\
\text { levels }\end{array}$ & $\begin{array}{l}\text { Operate a } \\
\text { House flood } \\
\text { plan }\end{array}$ \\
\hline$\%$ Adopted & 35.5 & 33.3 & 30.1 & 33.9 & 36.1 & 47 & 26.8 & 20.8 & 23.5 \\
\hline $\begin{array}{l}\% \text { not } \\
\text { Adopted }\end{array}$ & 63.95 & 66.7 & 69.9 & 66.1 & 63.9 & 53 & 73.2 & 79.2 & 76.5 \\
\hline Mean & 1.65 & 1.67 & 1.7 & 1.66 & 1.64 & 1.53 & 1.73 & 1.79 & 1.77 \\
\hline Median & 2 & 2 & 2 & 2 & 2 & 2 & 2 & 2 & 2 \\
\hline Mode & 2 & 2 & 2 & 2 & 2 & 2 & 2 & 2 & 2 \\
\hline Std. Dev & 0.49 & 0.473 & 0.46 & 0.475 & 0.482 & 0.501 & 0.444 & 0.407 & 0.425 \\
\hline Variance & 0.24 & 0.223 & 0.211 & 0.225 & 0.232 & 0.251 & 0.197 & 0.165 & 0.181 \\
\hline Range & 2 & 1 & 1 & 1 & 1 & 1 & 1 & 1 & 1 \\
\hline Minimum & 1 & 1 & 1 & 1 & 1 & 1 & 1 & 1 & 1 \\
\hline Maximum & 3 & 2 & 2 & 2 & 2 & 2 & 2 & 2 & 2 \\
\hline Sum & 302 & 305 & 311 & 304 & 300 & 278 & 317 & 328 & 323 \\
\hline
\end{tabular}

Table 7. Household Perceptions on the Implications of flood in Limbe

\begin{tabular}{|c|c|c|c|c|c|c|c|c|c|}
\hline \multicolumn{10}{|c|}{ Household Perception of the Impacts of flood in Limbe } \\
\hline Parameters & $\begin{array}{l}\text { Destruction } \\
\text { of Buildings }\end{array}$ & $\begin{array}{l}\text { Crop } \\
\text { Destruction }\end{array}$ & $\begin{array}{l}\text { Prevalence of } \\
\text { Water Borne } \\
\text { Diseases }\end{array}$ & Death & $\begin{array}{l}\text { Displacement } \\
\text { of Households }\end{array}$ & $\begin{array}{l}\text { Damage to } \\
\text { household } \\
\text { property }\end{array}$ & $\begin{array}{l}\text { Favor Crop } \\
\text { Growth }\end{array}$ & $\begin{array}{l}\text { Pollution } \\
\text { of well } \\
\text { water } \\
\end{array}$ & $\begin{array}{l}\text { Road } \\
\text { Destruction }\end{array}$ \\
\hline$\%$ Strongly Agree & 38.8 & 26.8 & 35.5 & 12.6 & 30.1 & 43.7 & 10.9 & 30.6 & 52.5 \\
\hline$\%$ Agree & 20.2 & 25.7 & 23.5 & 13.1 & 19.1 & 21.3 & 8.7 & 22.4 & 27.3 \\
\hline$\%$ Disagree & 30.1 & 31.7 & 30.1 & 46.4 & 36.6 & 23.5 & 53 & 31.7 & 13.7 \\
\hline$\%$ Strongly Disagree & 10.9 & 15.8 & 10.9 & 27.8 & 14.2 & 11.5 & 27.3 & 15.3 & 6.5 \\
\hline Median & 2 & 2 & 2 & 3 & 3 & 2 & 3 & 2 & 1 \\
\hline Mode & 1 & 3 & 1 & 3 & 3 & 1 & 3 & 3 & 1 \\
\hline Std. Deviation & 1.056 & 1.044 & 1.035 & 0.961 & 1.058 & 1.066 & 0.895 & 1.068 & 0.916 \\
\hline Variance & 1.115 & 1.09 & 1.072 & 0.924 & 1.119 & 1.137 & 0.801 & 1.141 & 0.839 \\
\hline Range & 3 & 3 & 3 & 4 & 3 & 3 & 3 & 3 & 3 \\
\hline Minimum & 1 & 1 & 1 & 1 & 1 & 1 & 1 & 1 & 1 \\
\hline Maximum & 4 & 4 & 4 & 5 & 4 & 4 & 4 & 4 & 4 \\
\hline
\end{tabular}

NB: $\mathrm{N}=183 ;{ }^{1}$ Overall Mean Decision for 4-point Likert scale questions is 2.5 (Mean value of below 2.5 is a tendency towards agreement $\left({ }^{\mathrm{a}}\right.$ Significant factor) while a mean score of above 2.5 to 4 is a tendency towards disagreement ( ${ }^{b}$ Not significant factor)

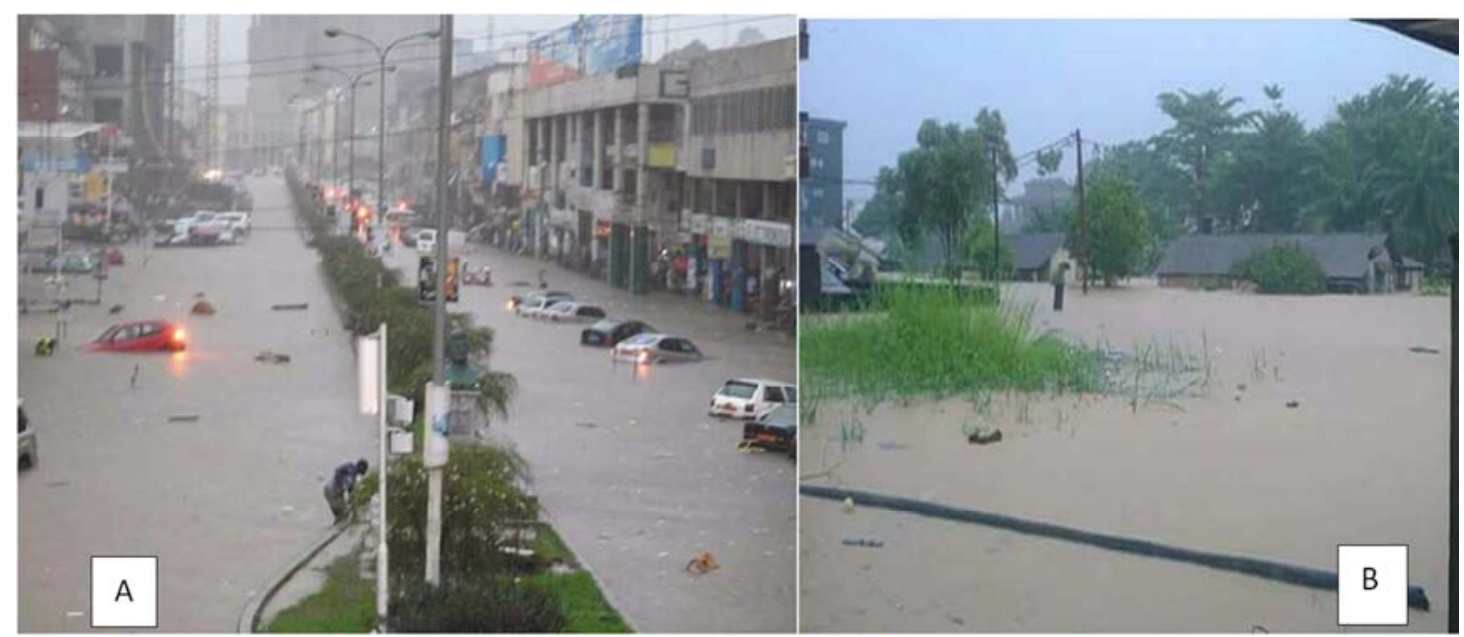

Figure 7. Evidence of flooding impacts in Limbe, 2018 (A) Major public access road affected by flood water (B) Residential houses submerged by flooding. 


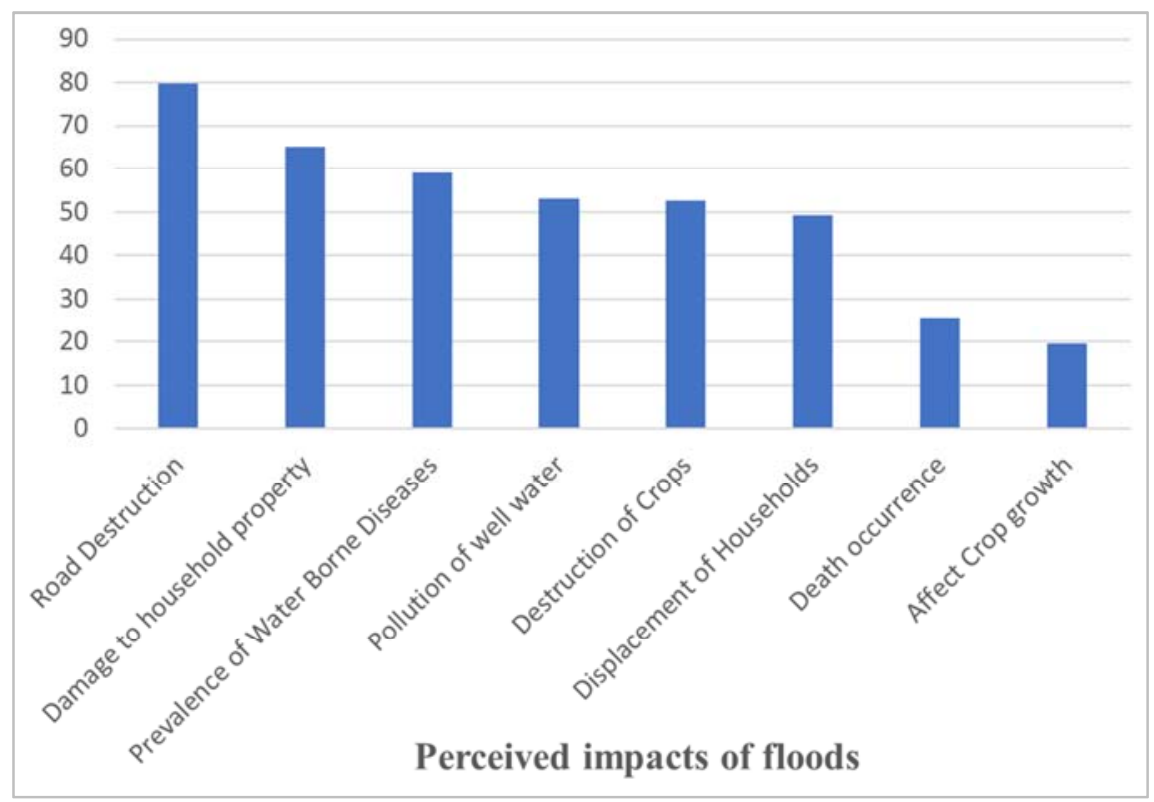

Figure 8. Ranked perceived impacts of floods based on the \% of households that agreed.

\subsection{Impacts of Flood Disaster}

With regards to the findings, flooding is the most predominant disaster in Limbe despite the adaptation strategies so far put in place. Flooding is most frequent in Limbe and the consequences have been grievous. Each year, the months of June to August are often characterized by heavy torrential rains causing serious distress to the local population and great embarrassment to the municipal authorities and local government officials. Nine impacts were identified by the researcher and they include; destruction of buildings, destruction of crops, prevalence of water borne diseases, loss of lives, displacement of households, damages to household property, increase crop growth, pollution of well water and destruction of roads. Using a four-point Likert scale analysis, a mean value of $2.5(1+2+3+4$ divided by 4$)$ was obtained. This is a weighted mean score from which the decision on household perception on the impact of flood was drawn. As such, a weighted value of below 2.5 indicates that the factor is significant while above 2.5 indicates that it is not significant. However, from Table 7 it can be seen that respondents perceived destruction of roads with a mean value of 1.73 as the most significant impact (Figure 7) followed by the damages of household property with a mean value of 2.03 , destruction of buildings with a mean of 2.13 , prevalence of water borne diseases with a mean of 2.16 , pollution of well water 2.32 , displacement of household 2.35 and destruction of crops 2.37 . While the non-significant impacts include death occurrences (2.90) and impact on crop growth (2.97). Figure 8 shows the ranked perceived impacts of floods based on the percentage of households that agreed. Floods are the most disastrous, frequent and widespread disaster causing extensive damage to lives and property. This therefore affirms the views of [43] that floods are by far the most hazardous, disastrous, frequent and widespread disaster throughout the world causing extensive damages to lives and property especially in developing countries where there are still bottle necks in achieving sustainable resilience.

\section{Conclusion and Policy Implications}

The Limbe municipality has suffered from devastating floods throughout the years and the residents are increasingly vulnerable to flood disasters. With flooding incidences unevenly distributed depending on one's location, the complexities of the urban environment and urbanization and social problems is evident. Slums and low residential areas are noted to be the most vulnerable to floods. In spite of the literature supporting the view that floods in Limbe are attributable to changes in climatic conditions (rainfall intensity), human factors have intensified the situation.

Frequency of flood occurrence, fatality of disaster and the extent of property damage were noted to vary among communities. The study recognized the need to sensitize and create awareness on environmental management, reinforce city planning and management, development control and enforcement. The Limbe municipality especially the study sites remain vulnerable to floods and this is a major urban challenge. Thus, there is a need to put in place urgent and robust measures targeted at reducing vulnerabilities and building a resilient city taking into consideration the peculiar vulnerabilities of various neighborhoods which has largely been ignored in the past.

1. There must be conscious efforts to clear chocked gutters, culverts and major drains in the city to ease water flows especially during the rainy seasons. Households should be encouraged to adopt best waste management practices through provision of dustbins and timely collection of refuse.

2. Land use planning, implementation and enforcement are very necessary in the current flood disaster challenges. With a good land use plan, areas uninhabitable are well 
marked out and a proper drainage system can be developed. City authorities and ministries must make sure proper plans are in place and enforced without any fear or favor. The Town and Country Planning Departments must provide and strengthen the necessary actions towards granting development permits, controlling building and construction codes and ensuring that they are strictly followed. This will go a long way to regulate building on waterways and development of slum settlements.

3. The council of Limbe should also ensure that there is a warning signal against the construction of houses in flood risk areas. No housing permits should be given to the occupants of these areas.

\section{References}

[1] Birkmann J. (2006a). Measuring vulnerability to promote disaster-resilient societies: conceptual frameworks and definitions. In: Birkmann J, editor. Measuring vulnerability to natural hazards - towards disaster resilient societies. New York: United Nations University. 9-54.

[2] Yodmani S. (2001). Disaster risk management and vulnerability reduction: protecting the poor. Asia and Pacific Forum for Poverty: reforming policies and institutions for poverty reduction, 5-9 February 2001. Manila: Asian Development Bank.

[3] UN. (2005). Hyogo framework for action 2005-2015: building the resilience of nations and communities to disasters. World Conference on Disaster Reduction, 18-22 January 2005, Kobe, Hyogo, Japan; [cited 2013 Mar 21]. Available from: http://www.unisdr.org/2005/wcdr/intergover/official-doc/L-do cs/Hyogo-framew ork-for-action-english.pdf.

[4] WCED. (1987). Our common future: report of the World Commission on Environment and Development (WCED). Brundtland Report. Oxford (UK): Oxford University Press.

[5] UN. 1993. Agenda 21: programme of action for sustainable development: the final text of agreements negotiated by governments at the United Nations Conference on Environment and Development (UNCED). 3-14 June 1992, Rio de Janeiro, Brazil. New York: United Nations Publications.

[6] Enarson, E. (2007). (Eds.), Emergency management: Principles and practice for local government (pp. 257-278). Washington, DC: International City and County Management Association.

[7] Balica, S. F. and Wright, N. G. and Vander Meulen, F. (2012) A Flood Vulnerability Index for Coastal Cities and Its Use in Assessing Climate Change Impacts. Natural Hazards, 64, 73-105

[8] Douben, K. J. (2006). Characteristics of River Floods and Flooding A Global Overview, 1985-2003. Irrigation and Drainage, 55, 9-21.

[9] Satterthwaite D. (2011). How Urban Societies Can Adapt to Resource Shortage and Climate Change. Philosophical Transactions of the Royal Society.

[10] Hardoy, Jorgelina and Patricia Romero Lankao. (2011). Latin
American cities and climate change: challenges and options to mitigation and adaptation responses. Current Opinion in Environmental Sustainability 3 (3): 158-163

[11] UNISDR. (2013.). Global assessment report on disaster risk reduction 2013.

[12] IPCC (Intergovernmental Panel on Climate Change) (2012a).: Meeting Report of the Intergovernmental Panel on Climate Change Expert Meeting on Geoengineering. [Edenhofer, O., R. Pichs-Madruga, Y. Sokona, C. Field, V. Barros, T. F. Stocker, Q. Dahe, J. Minx, K. Mach, G.-K. Plattner, S. Schlömer, G. Hansen, and M. Mastrandrea (eds.)]. IPCC Working Group IIITechnical Support Unit, Potsdam Institute for Climate Impact Research, Potsdam, Germany, 99 pp.

[13] IPCC (Intergovernmental Panel on Climate Change) (2014a). Summary for Policymakers. In: Climate Change 2014: Mitigation of Climate Change. Contribution of Working Group III to the Fifth Assessment Report of the Kadner, K. Seyboth, A. Adler, I. Baum, S. Brunner, P. Eickemeier, B. Kriemann, J. Savolainen, S. Schlo mer, C. von Stechow, T. Zwickel, and J. C. Minx (eds.)]. Cambridge University Press, Cambridge, United Kingdom and New York, NY, USA, pp. 1-30.

[14] Hijioka, Y., Lin, E., Pereira, J. J., Corlett, R. T., Cui, X., Insarov, G., et al. (2014). Chapter 24: Asia, change 2014: Impacts, adaptation, and vulnerability Part B: regional aspects, Cambridge, UK; New York: Cambridge University Press, pp. $1330-1347$.

[15] Mirza, M. M. Q. (2003). Climate Change and Extreme Weather Events: Can Developing Countries Adapt? Climate Policy 3 (3): 233-248.

[16] United Nations Framework Convention on Climate Change UNFCCC (2007). Climate Change: Impacts, Vulnerabilities and Adaptation in Developing Countries, Bonn: United Nations Framework Convention on Climate Change UNFCCC.

[17] Woodroffe CD (2003). Coasts: form, process and evolution. Cambridge University Press, Cambridge.

[18] McGranahan G, Balk D, Anderson B (2007) The rising tide: assessing the risks of climate change and human settlements in low elevation coastal zones. Environ Urban 19 (1): 17-37. doi: 10.1177/0956247807076960.

[19] Bates BC, Kundzewicz ZW, Wu S, Palutikof JP (eds) (2008). Climate change and water, technical paper of the intergovernmental panel on climate change. IPCC Secretariat, Geneva.

[20] Institute for Catastrophic Loss Reduction (ICLR), (2004). Telling the weather story. Insurance Bureau of Canada, Toronto.

[21] Songsore, J., Nabila, J. S., Yangyouro, Y., Amoah, E., Bosque-Hamilton, E. K., Etsibah, K. K., Gustafsson, J.-E., and Jacks, G. (2011). Regional Development in Ghana: The Theory and The Reality, (Woeli Publishing Services, New Edition, Accra) University of Ghana http://ugspace.ug.edu.gh.

[22] Mulungeta, G., Ayngli, S., Daby, O. P., Gudyanga, F., Lucio, F. and Durrheem, R. (2007). University of Ghana http://ugspace.ug.edu.gh 124 Natural and Human-Induced Hazards Disasters in Sub-Saharan Africa, Science Plan. ICSU Regional Office for Africa.

[23] UN Habitat (2014). The state of African Cities 2014: re-imagining sustainable urban transitions. United Nations Human Settlements Programme, Nairobi. 
[24] Intergovernmental Panel on Climate Change (2014) Climate Change 2014 - Impacts, Adaptation and Vulnerability: Regional Aspects. Cambridge University Press.

[25] Andrés Díez-Herrero and Julio Garrote (2020). Flood Risk Analysis and Assessment, Applications and Uncertainties: A Bibliometric Review. Water 2020, 12, 2050; doi: $10.3390 /$ w12072050.

[26] Wamsley, T. V.; Collier, Z. A.; Brodie, K.; Dunkin, L. M.; Raff, D.; Rosati, J. D. (2015). Guidance for developing coastal vulnerability metrics. J. Coastal Res. 2015, 31, 1521-1530 [CrossRef].

[27] McLaughlin, S.; Cooper, A. G. A (2010). Multi-scale coastal vulnerability index: A tool for coastal managers? Environ. Hazard. 2010, 9, 233-248 [CrossRef].

[28] Ndaley, Yannick Fonki, (2014). Heavy Rains Beat Limbe, Floods Put Residents in Distress. Eden Newspaper, 12 July 2014, (URL: http://edennewspaper.net/).

[29] Bang, H. N. (2013). Governance of disaster risk reduction in Cameroon: The need to empower local government. Journal of Disaster Risk Reduction Studies 5 (2): 1-10.

[30] Ndille Roland and Johannes A. Belle (2014). Managing the Limbe Floods: Considerations for Disaster Risk Reduction in Cameroon. Int J Disaster Risk Sci 5: 147-156.

[31] Njabe, R. K., and R. Fobang. (2006). Illustrated physical geography and map reading for Cameroon, 3rd ed. Limbe: Snway.

[32] UNISDR (United Nations International Strategy for Disaster Reduction). (2009). UNISDR terminology on disaster risk reduction (2009); [cited 2013 Jan 27]. Available from: http://www.unisdr.org/eng/terminology/terminology-2009-eng .html.

[33] UNISDR. (United Nations International Strategy for Disaster Reduction). (2002). Living with risk: a global review of disaster reduction initiatives. Geneva: UN Publications.

[34] UNISDR. (United Nations International Strategy for Disaster Reduction). (2004). Living with risk: a global review of disast (1) er reduction initiatives. Geneva: UN Publications.

[35] UNDP. (2004). Reducing disaster risk: a challenge for development. A global report, Bureau for Crisis Prevention and Recovery (BRCP). New York: UNDP.

[36] Kasperson J, Kasperson R, Turner BL, Hsieh W, Schiller A. (2005). Vulnerability to global environmental change. In: Kasperson J, Kasperson R, editors. The social contours of risk, volume II: risk analysis, corporations \& the globalization of risk. London: Earth- scan; p. 245-285.

[37] Kasperson RE, Dow K. (2005). Vulnerable people and places. In: Hassan R, Scholes R, Ash N. editors. Ecosystems and human well-being: current state and trends. Washington (DC): Island Press; p. 143-164.

[38] . Balica SF, Wright NG (2009) A network of knowledge on applying an indicator-based methodology for minimizing flood vulnerability. Hydro Process 23 (20): 2983-2986.

[39] . Cendrero A, Fischer DW (1997). A procedure for assessing the environmental quality of coastal areas for planning and management. J Coast Res 13: 732-744.

[40] Jejal Reddy Bathi and Himangshu S. Das (2014). Vulnerability of Coastal Communities from Storm Surge and Flood Disasters Int. J. Environ. Res. Public Health 2016, 13, 239.

[41] Stanturf, J. A, Warren M. L, Charnley, S. Polasky, S. C, Goodrick, S. L, Armah, F and Nyako, Y. A. (2011). Ghana Climate Change Vulnerability and Adaptation Assessment. United States Agency for International Development (USAID).

[42] IPCC (Intergovernmental Panel on Climate Change) (2007).: The Physical Science Basis: Contribution of Working Group, I to the Fourth Assessment Report of the Intergovernmental Panel on Climate Change (M. Parry, O. Canziani, J. Palutikof, P. van der Linden, \& C. Hanson, Eds.), Cambridge; New York: Cambridge University Press.

[43] Dhār O. N. and Nandargi, S. (2001). A Comparative Flood Frequency study of Ganga and Brahmaputra River system of North India - a brief appraisal. Water Policy 3: 101-107.

[44] Anomanyo, Edward D. (2004). "Integration of Municipal Solid Waste Management in Accra (Ghana): Bioreactor Treatment Technology as an Integral Part of the Management Process. "Thesis. Lund University, Sweden, 2004.

[45] Fobil Julius N 1, Nathaniel A Armah, Jonathan N Hogarh, Derick Carboo (2007). The influence of institutions and organizations on urban waste collection systems: an analysis of waste collection system in Accra, Ghana (1985-2000). (2007) J Environ Manage Jan; 86 (1): 262-71. doi: 10.1016/j.jenvman.2006.12.038. Epub 2007 Feb 8.

[46] Aboagye D (2012) The political ecology of environmental hazards in Accra, Ghana. J Environ Earth Sci 2 (10): 2224 32161 .

[47] Erica Tauzer, Mercy J Borbor-Cordova, Jhoyzett Mendoza, Telmo De La Cuadra, Jorge Cunalata, Anna M Stewart-IbarraI (2019). A participatory community case study of periurban coastal flood vulnerability in southern Ecuador. PLoS ONE 14 (10): e0224171. https://doi.org/10.1371/journal.pone.0224171.

[48] Coutio, Ruth Zugman, (2004). APELL and Floods; A Community-Based Approach for Disaster Reduction. UNEP/UNESCO. Paris, France. 4 p.

[49] Olorunfemi, F. B. (2011). Managing Flood Disasters under a Changing Climate: Lessons from Nigeria and South Africa. Nigerian Institute of Social and Economic Research (NISER). Discussion Paper No. 1, 201. pp 412. Pilon, P. J. (1999). Guidelines for reducing flood losses. (UN, ISDR, DESA, UN, ESCAP, WMO). USA. pp 22-38.

[50] Gyekye, K. A. (2011). Geomorphic Assessment of Floods within the Urban Environment of Gbawe-Mallam, Accra. Ghana Journal of Geography Vol. 3 2011. pp 151-177.

[51] Chinh Luu, Hieu Xuan Tran, Binh Thai Pham, Nadhir Al-Ansari, Thai Quoc Tran, Nga Quynh Duong, Nam Hai Dao, Lam Phuong Nguyen, Huu Duy Nguyen, Huong Thu Ta, Hiep Van Le, and Jason von Meding (2020). Framework of Spatial Flood Risk Assessment for a Case Study in Quang Binh Province, Vietnam. Sustainability 2020, 12, 3058; doi: $10.3390 /$ su12073058. 


\section{Biography}

Usongo Patience Ajonina is a senior lecturer and researcher in the Department of Geography, University of Buea, Cameroon. She has published several articles in peer reviewed academic journals internationally.

Tepoule Nguéke Joseph is a lecturer and researcher in the Department of Geography, University of Buea, Cameroon. He has published several articles in peer reviewed academic journals internationally.

Chang Linda Meh is a post graduate student in the department of Geography University of Buea, Cameroon. 